\title{
Using Lactobacillus as probiotic to inhibit growth and adhesion of Proteus mirabilis causing urinary tract infection
}

\author{
استخلام بكتيريا probiotic S Lactobacillus لمنع نمو و التصاق بكتيريا \\ Proteus mirabilis
}

\section{Abdul-Wahid Baqir Al-Shebani \\ Ghydaá H. Al-Jeboury*}

Biotechnology Dep. / College of Science/ Al-Nahrain University

*Biotechnology Research Center/ Al-Nahrain University

\section{Abstract}

The aim of the study was to use lactic acid bacteria (LAB), as probiotic, to treat growth and adhesion property of Proteus mirabilis isolated from patients suffering from urinary tract infection (UTI). For this purpose, one P. mirabilis isolate (P.M.9) was selected out of 9 isolates obtained from 150 urine specimens. Due to its resistance to 11 antibiotics tested, this isolate was treated with three-fold concentrated filtrates of two lactobacillus isolates (as probiotic). Results after treatment, showed that the filtrates exhibited significant inhibitory effect against the pathogenic P.M.9 and its adhesion property especially when only an average of 3-10 bacteria /cell were adhered to each epithelial cell compared to 44-55 bacteria/cell.

\section{المستخلص}

هدفت الدراسة الى امكانية استخدام بكتيريا حامض اللاكتيك Probiotic (LAB) لمعالجة نمو و صفة التصاق بكتيريا Proteus mirabilis المعزولة من مرضى يعانون من التهاب المجاري البولية (UTI) ـ لهذا الغرض اختيرت عزلة P.m.9 من مجموع 9 عزلات تم عزلها من 150 عينة ادرار مرضى التهاب المجاري البولية اعتمادا

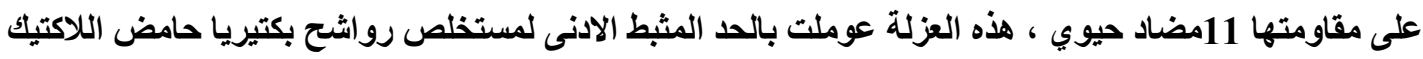
( اظهرت النتائج بعد المعاملة ان مستخلص بكتيريا حامض اللاكتيك يمتلك قابلية تثبطية ضد (Probiotic) البكتيريا الممرضة P.M.9 و صفتها الالتصاقية خصوصا وان معدل الالتصاق تراوح بين 10-3 بكتيريا/خلية مقارنة بمعدل الالتصاق قبل المعاملة والذي يتراوح بين 44-55 بكتيريا/خلية . 


\section{Introduction:}

During the last decades, microorganisms and their metabolic products were broadly used in treatment of various diseases and infections. Normal flora, such as lactic acid bacteria (LAB), found in the gastrointestinal tracts can produce different types of materials; organic acids, ammonia, hydrogen peroxide, diacetyl, bacteriocins and other compounds which had been used as inhibitory means against pathogenic bacteria. $\mathrm{LAB}$ were used to treat gastric disturbance, colon irritation, diarrhea and even colon carcinom [1]. One of the most common causes of UTI is Proteus mirabilis which have many various virulence factors, such as adhesion, swarming, urease, hemolysin and protease production that causing infection [2]. Adhesion is the initial step of Proteus mirabilis infection [3]. Investigations suggested that pili are the adherence element responsible for binding uropathogenic Proteus mirabilis to uroepithelium [4]. Adhesion involves complex interaction between pili and specific complex carbohydrate (as receptors) of host cell membrane [5]. It was found that probiotic (LAB isolates) have inhibitory effect on the adherence of bacteria, and can alter some surface structures of gram negative bacteria without killing it [6].

The adherence of bacteria to biological surface is a complex process which often involves lock and key type interaction between bacterial attachment fimbriae and specific complex carbohydrate structures of the host cell membrane (receptors). It was also found that bacteria which are high adherence are more virulent than that of less adherent ability [7].

The word Probiotic is derived from the Greek and means (forlife). It was first used by [34]. Probiotic is a microbial dietary adjuvant that beneficially affects the host physiology by modulating mucosal and systemic immunity, as well as improving nutritional and microbial balance in the intestinal tract [8]. Currently probiotic preparations contain, Lactobacillus acidophilus, Lactobacillus Plantarum, Lactobacillus casei, Lactobacillus fermentum, Lactobacillus lactis,(9).

\section{Aims of the Study}

A- Isolation and identification of Proteus from patients suffering from UTI.

B- Isolating the most antibiotics-resistant isolate of Proteus mirabilis to be used in the probiotic experiment. 
C- Investigating the inhibitory effect of LAB isolates against the pathogenic Proteus mirabilis.

D- Determining the inhibitory effect of LAB filtrates on the adhesion property of Proteus mirabilis isolate.

\section{Materials and methods}

\section{Urine sample collection:}

Mid stream urine samples specimen were collected in sterile tubes from patient of AL-Karama hospital and AL-Yarmoq hospitals in Baghdad. A total of 150 samples were aseptically collected and transported to the laboratory as fast as possible.

Two isolates of identified LAB were taken from Biotechnology Department/College of Science/AlNahrain University (Lactobacillus plantarum and_Lactobacillus acidophilus).

\section{Isolation of $P . M$ :}

One loopfull of undiluted urine sample was spread on blood agar and MacConkey agar plates. Plates were then incubated over night at $37^{\circ} \mathrm{C}$. Single colonies which were non lactose fermenters, and gave negative reaction to oxidase test and making swarming on blood agar were transferred to blood and MacConkey agar. The process was repeated several times for purity before use for further diagnosis.

Microscopic Examination of Proteus mirabilis: A loopfull of Proteus isolates was fixed on a microscopic slide, then stained by gram stain to examine cells shape, grouping, reaction and non-spore forming [10].

\section{Api 20E Identification for Proteus mirabilis Isolates:}

Identification was carried out by subculturing of selected colonies grown on MacConkey agar into Api 20E microtubes gallery. This system is designed for the performance of more than 20 standard biochemical tests from a single colony grown on plating medium. Each test in this minimized system is performed within a sterile plastic microtube which containing appropriate substrates and was fixed to an impermeable plastic strip (gallery) each gallery contain 20 microtubes including the biochemical test and sugar fermentation. Inoculation of the galleries was done with sterile pasture pipette and five $\mathrm{ml}$ of tap water dispensed into tray provide a humid atomsphere then incubated at $37{ }^{\circ} \mathrm{C}$ for $24 \mathrm{hr}$. After that reagent added for reading the galleries, each positive reaction was given a value 1,2 or 4 according to the position of the test in its group, so a value from 0 to 7 digit observed was then looked up in the 
index and the identification is determined.

Sensitivity of Proteus mirabilis to Antibiotics:

Ten $\mathrm{ml}$ of nutrient broth were inoculated with each bacterial isolate, then incubated at $37{ }^{\circ} \mathrm{C}$ to $\log$ phase (O. D. 600 about 0.35$)$ giving $\left(1 * 10^{8}\right)$ cell $/ \mathrm{ml}$ of broth. Then, $0.1 \mathrm{ml}$ of the inoculated broth was transferred and spread by rotating the plate approximately $60^{\circ}$ each time to obtain an even distribution of the inoculums. The inoculated plates were then placed at room temperature for 30 minutes to allow absorption of excess moisture. With a sterile forceps the selected antibiotic disks were placed on the inoculated plates and incubated at $37^{\circ} \mathrm{C}$ for $18 \mathrm{hr}$ in an inverted position. After incubation, the diameter of inhibition zones was measured by a ruler $(\mathrm{mm})$. Results were recorded and compared according to the National Committee for Clinical Laboratory Standards [11].

Bacterial Adhesion Test (12)...

Preparation of Proteus mirabilis Suspension:

Ten milliliter of nutrient broth medium was inoculated with bacterial growth, the culture was then incubated at $37^{\circ} \mathrm{C}$ for over night (O. D.600 about 0.4) giving $\left(1 * 10^{9}\right)$ cell / ml. cultures of bacteria were washed twice with PBS and centrifuged at $1000 \mathrm{rpm}$ for 20 minutes and resuspending in PBS.

Preparation of Epithelial Cells:

Uroepithelial cells were isolated from the urine of some healthy females by centrifugation at $1000 \mathrm{rpm}$ for 5 minutes then washed three times with PBS and centrifuged at $1000 \mathrm{rpm}$ for 10 minutes before resuspended in PBS.

\section{Adhesion Test:}

- A mixture of $0.2 \mathrm{ml}$ of the bacterial suspension, $0.2 \mathrm{ml}$ of the epithelial cells suspension and $0.1 \mathrm{ml}$ of $\mathrm{PBS}$ was incubated at $37{ }^{\circ} \mathrm{C}$ for one hour.

- Unattached bacteria to uroepithelial cells were removed by centrifugation in PBS at $1000 \mathrm{rpm}$ for 10 minutes.

- The final pellet was resuspended in PBS then a drop was placed onto a microscope slide, air-dried fixed with methanol : acetic acid (3:1) and stained with methylene blue.

- The adherent bacteria to epithelial cells were observed by the compound light microscope.

Control of only epithelial cells was included.

\section{Determining Inhibitory Effect of}

LAB:

On Solid Medium (MRS Agar): A culture of LAB previously grown in MRS broth was streaked on MRS agar, and then incubated under anaerobic 
conditions at $37^{\circ} \mathrm{C}$ for $24 \mathrm{hr}$ [13]. After incubation a cork porer $(5 \mathrm{~mm})$ was used to withdraw discs of $\mathrm{LAB}$ growth and placed on surface of the nutrient agar that was inoculated (before) with $0.1 \mathrm{ml}$ of pathogenic bacteria. After incubation, at $37^{\circ} \mathrm{C}$ for $24 \mathrm{hr}$, the inhibition zone around the disc was measured in $(\mathrm{mm})$. Same procedure was repeated by using different incubation times of LAB (18, 24 , and $48 \mathrm{hr}$ ) to determine the optimum incubation time that gives greater inhibition effect.

In Liquid Medium (MRS Broth):MRS broth was inoculated with $1 \%$ of LAB culture, then incubated anaerobically at $37^{\circ} \mathrm{C}$ for different period of times $(18,24$ and $48 \mathrm{hr}$ ) [14]. After incubation the culture was centrifuged at $6000 \mathrm{rpm}$ for 15 minutes, the supernatant

was obtained. After adjusting the $\mathrm{pH}$ of the filtrate to 6.5 by using $\mathrm{NaOH} 0.4 \mathrm{~N}$ $(1 \mathrm{ml})$, it was filtered through Millipore filter unit $(0.22 \mu \mathrm{m})$. Then well diffusion method that mentioned by [15] was used; when nutrient agar plates which was

\section{Results and Discussion}

Isolation of Proteus Isolates:

One hundred and fifty midstream urine samples were collected from patients suffering from symptoms referred as urinary tract infection. It was found that $116(77.3 \%)$ out of the total 150 samples inoculated with $0.1 \mathrm{ml}$ of each pathogenic bacteria by a spreader. Then $(5 \mathrm{~mm})$ wells were made by a cork porer. Each well was filled with the LAB filtrate, and then incubated at $37^{\circ} \mathrm{C}$ for $(18,24$ and 48 hr).

Effect of Concentrated Filtrate on Adhesion of Proteus mirabilis:The minimum inhibitory concentration of the concentrated filtrate of LAB isolates was used to investigate the effect on adhesion property of Proteus mirabilis. For this purpose method described by [12] was applied which was mentioned previouslywith the addition of the following steps:

- Nutrient broth medium containing minimum inhibitory effect of concentrated filtrate was dispensed in sterile tubes and incubated with a loopfull of liquid culture of Proteus mirabilis, then incubated for $24 \mathrm{hr}$.

- Bacterial adhesion test was done as indicated previously. Adhesion free concentrated filtrate was prepared as control.

collected gave positive results on MacConkey agar and Blood agar. These results were near to those reported by [16] and [17] who found that the percentage of positive cultures of urine samples were $(84 \%)$ and (83\%) 
respectively. But such results were in disagreement with those of [18] in Zymbaboy when found that percentage of positive culture of urine samples was $(27 \%)$. The reason of the differences in percentage may be owed to differences in size and number of hospital surveyed as well as to the season and medications before sampling.

Results indicate that Proteus found in both sexes, but its percentage of isolation in male samples was higher (62.5\%) when 10 isolates were belonged to them, while $(37.5 \%)$ percentage of isolation in female when 6 isolates were belonged to them, this result agree with those reported by [19] who found that the percentage of isolation of Proteus in male was $(63.5 \%)$ while it was $(36.5 \%)$ in female. However, effect of vaginal fluid could be suggested as a killer agent in female which has low $\mathrm{pH}$ may act naturally as a selection pressure against Proteus [20].

\section{Identification of Proteus mirabilis:}

\section{Cultural Characteristics:}

In accordance to their pale colony appearance on MacConkey agar as non lactose fermenters, and swarming motility on blood agar after $24 \mathrm{hr}$ incubation, the suspected isolates are considered to be as Proteus isolates which require more identification processes to be identified for species.
Morphological

Characteristics:

microscopical examination, Gram staining examination, showed that cells of the suspected isolates appeared purple, non spore former, rods and motile.

Moreover, identification of the isolates was confirmed by using Api system (Api 20E) the findings obtained by the conventional biochemical tests.

\section{Antibiotics Sensitivity of Proteus mirabilis:}

The emergence of prevalence of antibiotic resistance strains is considered as a major therapeutic problem that could be explained by several hypothesis such as, the influence of excessive and or inappropriate antibiotic use, transmission of resistant isolates among people, consumption of food from animals that had received antibiotics, and greater mobility of individual worldwide have also contributed to the extension of antibiotic lresistance[21].

In this study the effect of antibiotic on Proteus mirabilis was tested by using standard disk diffusion method, and results obtained were compared with those of NCCLs, (1991). Antibiotic resistance among Proteus mirabilis isolates varied according to the nature of the isolate or antibiotic. Among them no single antibiotic was resisted by all the isolates of Proteus mirabilis or sensitive to it. However, amikacin was the most 
effective antibiotic when only one isolate (Pm4) of Proteus mirabilis resisted it, while all others were sensitive. Ciprofloxacin was the second highly effective antibiotic when all isolates, expect two (Pm3 and Pm9), were exept resistant to it. Gentamycin was the third expect three (Pm1, Pm7 and Pm9), were resist to it. On the other hand, penicillin $\mathrm{G}$ was the least effective antibiotic because all isolate, expect $(\mathrm{Pm} 7)$, were sensitive to it.

Followed by amoxicillin, chloramphenicol and tetracycline which were sensitive by only two isolate each. The results reported in this investigation, that isolate $P . m 9$ was the strongest isolate which was resisted to almost all antibiotics, so it selected from other isolates to study the adhesion property and the inhibitory effect of LAB.

\section{Adhesion of Proteus mirabilis:}

Ability of Proteus mirabilis to adhere to uroepithelial cells is considered as an important virulence factor in pathogenesis of urinary tract infections. In this study, adherence property of Proteus mirabilis as well as how this property may be affected by LAB isolates was investigated. Adherence ability of Proteus mirabilis to uroepithelium which observed by viewing under oil-immersion of the compound light microscope which was include the uroepithelium from healthy female and the infected uroepithelium (UEP), where the P. m. 9 appeared as rod and adhere to the uroepithelium (by pili), the results show that the highest number of adhering bacteria to UEP (rang from 45-55 bacteria/cell) recorded by isolate P. m. 9, this result almost in agreement with that recorded [22] who found that the highest number of mucous strain of Pseudomonas aerogi nosa adher to the tracheal epithelium was 45 bacteria/cell, but disagreed with the result of [4] that the highest number of adherent of Proteus mirabilis to UEP was 29 bacteria/cell. Proteus mirabilis usually has fimbriae which are considered as adherence elements responsible for binding of uropathogenic Proteus mirabilis to uroepithelial cell [4]. [22] stated that mucoid strains of Pseudomonas aeroginosa contain two adherence elements namely fimbriae and alginate.

\section{Inhibitory Effect of LAB:}

\section{On Solid Medium (MRS Agar):}

Propagating LAB isolates on MRS agar under anaerobic conditions was the most efficient method for production of their inhibitory metabolites against tested pathogenic bacteria. Despite that all LAB isolates, exhibited serious inhibitory effect on Proteus mirabilis isolates, an inhibitory effect of LAB 
isolates $L b . a .11$ was the most effective against $P$. m. 9, where as Lb. p.3 also have effect on P. m. 9 but less than $L b . a$. 11, when inhibitory zone reached 18.5 $\mathrm{mm}$ after $24 \mathrm{hr}$ incubation time, while Lb. p. 3 have $17 \mathrm{~mm}$ after the same incubation time. Moreover, such LAB isolate ( $L b . a .11)$ was effective against P. m. 9 it also gave highest inhibition zone against the other P. m. isolates for both incubation time (18 and $24 \mathrm{hr}$ ). Results showed that the general that almost all LAB isolates exhibited better inhibitory effect on $P . m$. isolates after incubation for $24 \mathrm{hr}$. Generally incubation period of $(24 \mathrm{hr})$ resulted in production of more inhibitory effect by almost all LAB isolates against all P. m. isolates than the incubation period of 18 hr. However, when longer incubation periods (30 hr and more) were tested on some isolates result in no difference in inhibition zone were recorded or, in some times lower. Lb. p. have also inhibitory effect against tested isolates and its effect increased after (24 hr) incubation $(24 \mathrm{hr})$ and this was it could be due to lactocidin which produce from Lb. p. [23] and due to plantaracin which was active against the tested isolates [24]. While the Lb. a. have the highest inhibitory effect after $(24 \mathrm{hr})$ incubation and this was due to acidophilin produce from Lb. a. [25].

LAB have an inhibitory effect against gram negative and positive bacteria [26]. [27] stated that LAB has a high inhibitory effect against enteropathogenic bacteria. So the inhibitory effect of Lb. p 3 and Lb. a. 11 against P. m. 9 have the highest inhibitory effect

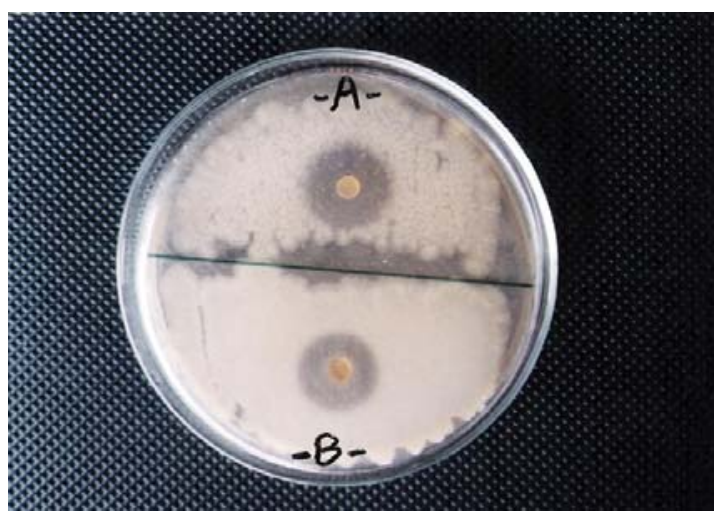

Plate (2): Inhibitory effect of Lactobacillus plantarum 3 and Lactobacillus acidophilus 11 against Proteus mirabilis 9 isolate (MRS agar). A- Lactobacillus acidophilus 11 after $24 \mathrm{hr}$. of incubation on MRS agar giving zone diameter of (18.5) $\mathrm{mm}$. B- Lactobacillus plantarum 3 after $24 \mathrm{hr}$ of incubation on MRS agar giving zone diameter of (17) $\mathrm{mm}$.

In Liquid Medium (MRS Broth): 
Inhibitory effect of LAB isolates grown in MRS broth was evaluated against the tested isolates of Proteus mirabilis. Well diffusion method was used by filling the wells which made in nutrient agar plates which is cultured the P. $m$. 9 with the filtrate of two LAB isolates (Lb. p. 3, Lb. a. 11). Selection of these two isolates depended on their ability in production best inhibitory effect. Maximum inhibition zone diameters reached $20 \mathrm{~mm}$ which is highest than that recorded by solid medium, this may be due to the existence in MRS broth exhibited a wide spectrum inhibitory effect against gram positive bacteria (Staphylococcus aureus, Bacillus subtilis) and gram negative bacteria (E. coli, Klebsiella spp., Proteus spp.) when the inhibition zone diameter ranged between (13-19)mm [28]. To study the effect of incubation time period in the liquid medium the two isolates of LAB were grown for $(18,24,48) \mathrm{hr}$. Incubation period of $24 \mathrm{hr}$ gave the best inhibitory effect by $L b . \quad p .3$ the inhibition zone diameter reached to 18 $\mathrm{mm}$ against tested Proteus mirabilis isolates. Increasing incubation period to $48 \mathrm{hr}$ resulted in least inhibitory effect for Lb. p. 3 isolates. Lb. a.11 also gave optimum inhibitory effect after $24 \mathrm{hr}$ incubation and not after $48 \mathrm{hr}$, the reason for such two LAB isolates may be that the inhibitory materials (acidophilin, plantaracin) loose activity when secreted outside the cells after increasing the incubation time. The investigation also includes the inhibitory effect of concentrated filtrates on tested isolate. The filtrates of Lb. p. 3 and Lb. a. 11 were concentrated three fold by using freeze-dryer. The first and second fold of concentrated filtrates of $L b . p .3$ have zone diameter $(20,21) \mathrm{mm}$, respectively against $P$. m. 9 while first and second fold of concentrated filtrates of $L b . a .11$ have zone diameter $(21,23) \mathrm{mm}$, respectively against $P . m$. 9, while the third fold has the highest inhibitoryeffect after $24 \mathrm{hr}$ incubation because all the inhibitory substances was concentrated, zone diameter of $L b$. p. 3 against $P$. m. 9 reached to $27 \mathrm{~mm}$ and Lb. a. 11 against P. m. 9 have zone diameter reached to $30 \mathrm{~mm}$. Incubation time of $18 \mathrm{hr}$ and $48 \mathrm{hr}$ gave inhibitory effect less than effect after $24 \mathrm{hr}$ incubation so [29] stated that there is a relationship between the diameter of inhibition zone and the concentration of inhibitory substances. On the other hand [30] mentioned that death of tested bacteria increased by the increasing of inhibitory substances like bacteriocin and acidophilin and plantaracin of LAB. 


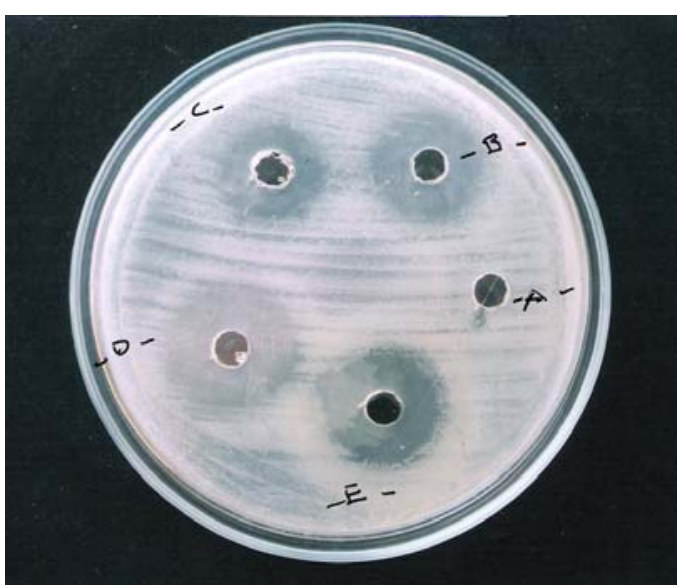

Plate (5): Inhibitory effect of concentrated filtrates for Lactobacillus plantarum 3 and Lactobacillusacidophilus 11 against Proteus mirabilis 9 isolate. A- Control (contain concentrated MRS). B- Lactobacillus acidophilus 11 concentrated filtrate after $18 \mathrm{hr}$. incubation in MRS broth resulted zone of inhibition with (25) $\mathrm{mm}$ diameter. CLactobacillus plantarum 3 concentrated filtrate after $18 \mathrm{hr}$. incubation in MRS broth resulted zone of inhibition with (23) $\mathrm{mm}$ diameter. D- Lactobacillus acidophilus 11 concentrated filtrate after $24 \mathrm{hr}$. incubation in MRS broth resulted zone of inhibition with (30) $\mathbf{m m}$ diameter. E- Lactobacillus plantarum 3 concentrated filtrate after $24 \mathrm{hr}$. incubation in MRS broth resulted zone of inhibition with (27) $\mathrm{mm}$ diameter

Adhesion Inhibition by LAB Filtrates:

The initial step in the infection of host cells by Proteus mirabilis to the host cell is the adhesion so interference with adhesion process cause a prevention of infection. Effect of concentrated filtrates of LAB against adhesion property of Proteus mirabilis was investigated using [12]. Results obtained showed that the three-fold concentrated filtrated of LAB isolates (Lb. p. 3 and $L$ b. a.11) against tested P. m.9 was observed to minimizing adhesion of $P . m .9$ to the uroepithelial cells reaching an average of (3-10) bacteria/cell. It was clearly observed that the adhesion of P. m. 9 to UEPCs was clearly minimized. This may be due to the effect of the inhibitory substances found in the filtrates of the LAB isolates and to the acidic $\mathrm{pH}$ which affect growth of the gram negative bacteria by altering some surface structures (like pili), leading to prevent bacterial cells from adhesion to UEPCs with out killing the bacteria [6]. Some authors were reported partial and complete inactivation of adherence of several gram negative uropathogenes.they investigated the inhibitory effect produced by Lactobacillus casei on E. coli (which is also uropathogenic), and found that the inhibitory effect was not caused by the bacteriophage or hydrogen peroxide but due to the coaggregation of E. coli and $L b . c$. in urine which was occurred after 
$20 \mathrm{hr}$ at $37^{\circ} \mathrm{C}$. The prevalence of inhibitory-producing $\mathrm{LAB}$ on the uropathogenes and the ability of LAB to interact closely with the uropathogenes seem to constitute an important host defense mechanism against infection [31]. [32] reported that precoating of LAB strains reduced the binding of uropathogenic coagulase-negative
Staphylococci and E. coli to 8 bacteria/ cell, So biosurfactant surlactin as released by Lactobacillus isolates may open the way to the development of antiadhesive biologic coating against Enterococcus faecalis, they reported a decrease in the percent of adhering Enterococcus which was reach to approximately $70 \%$.

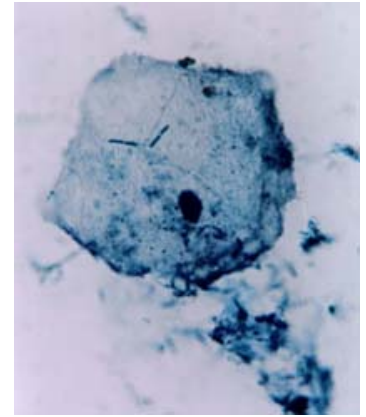

$-A-$

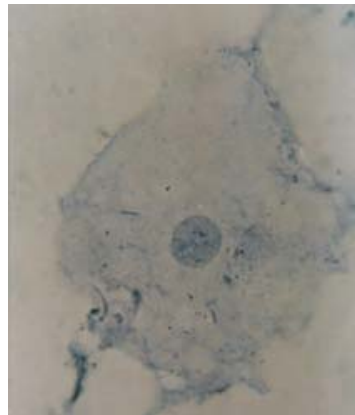

-B-

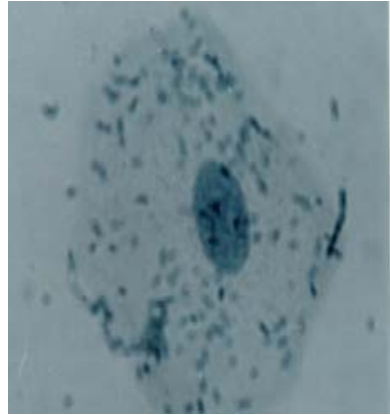

$-\mathrm{C}-$

Microscopical examination of adhesion of Proteus mirabilis cells to uroepithelium cells $(1000 x)$. A: after treating Proteus mirabilis (P. m. 9) with three-fold filtrate of probiotic LAB (isolate Lb. p. 3), B: Proteus mirabilis (P.m.9) with probiotic treating three-fold filtrate of LAB (isolate Lb. a. 11), C: Adhesion of Proteus mirabilis (isolate P. m. 9) .

\section{References}

1- Donohue, D. C. and Salminen, S. (1996). Safely of probiotic bacteria. Asia Paciffic J. Clin. Nutr., 5: 25-28.

2- Mobley, H. L. T. and Belas, R. (1995). Swarming and pathogenicity of Proteus mirabilis in the urinary tract. Tends in Microbiol. 3 (7): 280-284.

3- Mobley, H. L. T. and Chippendle, G. R. (1990). Hemaglutinin urease and hemolysin production by Proteus mirabilis from clinical sources. J. Infec. Dis. 161: 525-530.
4- Wray, S. K. Hull, S. I. Cook; R. C. Barrish, J. and Hall, R. A. (1986). Identification and characterization of a uroepithelial cell adhesion from a uropathogenic isolate of Proteus mirabilis. Inf. Immun. 54 (1): 43-49.

5- Jackson, E; Fowler, J. R. and Thomas, A. Stamey. (1997). Studies of introital colonization in women with recurrent urinary infections UTI: The role of bacterial adherence, J. Urol. 117: 472607. 
6- Chan, R. C.; Bruce, A. W. and Reid, G. A. (1984). Adherence of cervical, vaginal and distal urethral normal microflora to human uroepithelial cells and the inhibition of adherence of gramnegative uropathogens by competitive exclusion, J. Urol. 131: 596-601. (Cited by Fergus M. C. (1999).

7- Gruickshank, R. H. A.; Dugend J. P.; Dugenud, B. P.; Marmion, B. P. and Swain, R. H. A. (1975). Medical Microbiology. 2 (12 ${ }^{\text {th }}$ ed.). Logram Group Limited. Britai.

8- Lister, J. A. (1873). Further contribution to the natural history of bacteria and the germ theory of fermentative changes, Quart. J. Microsc. Sci 13: 380-408. (Cited by Fergus 1999).

9- Tissier, H. (1905). Taxanomy and ecology of Bifidobacteria, Bifidobacteria microflora.3: 11-28. (Cited by Fergus 1999).

10-Atlas, R. M.; Brown, A. E.; Parks, L. C. (1995). Laboratory Manual of Experimental Microbiology. ( $1^{\text {st }}$ ed). Mosby. Inc. Missouri.

11-National Committee for Clinical Laboratory Standrs (1991). Performance Standard for Antimicrobial Susceptibility Testing. Third informational supplement. Document $\mathrm{M}$ 100-41; 11 (17), NCCLs, Villanva. Pa. 12-Iwahi, T., Abc, Y. and Tsuchiya, K. (1982). Virulence of $E$. coli in a sending urinary tract infection in mice. J. Med. Microbiol. 15: 303-316.

13-Silva, M.; Jacobus, N. V.; Deneke, C. and Gorbach, S. L. (1987). Antibacterial substances from a human Lactobacillus strain. Antimicrob. Agent and Chemother.; 31 (8): 1231-1233

14-Schillinger, U. and Luck, F. K. (1991). Antibacteial activity of Lactobacillus sake isolated from meat. Appl. Environ. Microbiol., 55 (8): 1901-1905.

15-Vignolo, G. M.; Suriani, F., Halgado, A. P. R. and Oliver, G. (1993). Antibacterial activity of Lactobacillus strains isolated from dry fermented sausages. J. Appl. Bacteriol., 75: 344349

16-Younis, A. T. (1986). Effect of the heamolysin of E. coli causing UTI on phagocyte cells. M. Sc. Thesis, College of Medicine. University of Baghdad. Iraq.

17-Al-Bayati, Z. G. F. (1999). Identification of bacterial strains isolated from patients with urinary tract infection and the role of plasmids in their antibiotic resistance. M. Sc. Thesis, College of Science. Al-Nahrain University. Baghdad. Iraq

18-Obi, Cl.; Traupiwa, A. and Simango, C. (1996). Scope of urinary pathogens isolates in the public health bacteriology laboratory, Harare. Antibiotic susceptibility pattern of isolates and 
incidence of hemolytic bacteria. Cent. Afr. J. Med. 42: 244-249.

19-Al-Murjany, M. F. S. (2000). Study the multiple antibiotic resistance and some of virulence factor for Proteus mirabilis which cause UTI, and study plasmid contain. M. Sc. Thesis, College of Science. AL-Mustansiryah University. Baghdad. Iraq

20-Stamey, T. A. (1975). A clinical classification of UTI based upon origin sothern. Med. J. 68: 934-939.

21-Sotto, A.; Boever, C. M.; Fabbro-peray, P.; Gouby, A.; Sirot, D. and Jourdan, J. (2001). Risk factors for antibioticresistance Escherichia coli isolated

22-Ramphal, R.; Sadoff, J. C.; Pyle, M. and Silipigni, J. D. (1984). Role of pilin in the adherence of $P$. aeroginosa to injured tracheal epithelium. Infec. Immun. 44: 38-40. Speck, M. L. (1971). Control of food born pathogens by starter cultures. J. Dairy Sci., 55 (7): 1019-1022.

23- Speck, M. L. (1971). Control of food born pathogens by starter cultures. J. Dairy Sci., 55 (7): 1019-1022

24- Olasupo, N. A.; Olukoya, D. K. and Odunfa, S. A. (1995). Studies on bacteriocinogenic Lactobacillus isolates from selected Nigerian fermented foods. J. Basic Microbiol, 35 (5): 319-324. (Abst).
25- Gilliland, S. E. and Speck, M. L. (1972). Interaction of food starter cultures and food born pathogens: Lactic Streptococci versus, Staphylococci and Salmonella. J. Miller Food Technol., 35 (5): 307-310.

26- Nigatu, A. and Gashe, B. A. (1994a). Inhibition of spoilage and food borne pathogene by lactic acid bacteria isolated from fermenting tef (eragrostis tef) dough. Ethiop. Med. J., 32: 223229.

27- Gupta, V.; Radramma; Rati, E. R. and Joseph, R. (1998). Nutritional quality of lactic acid fermented better gourd and fenugreck leaves. International Journal of Food Science and Nutrition. 49 (2): 101-108

28- Fang, W.; Shi, M.; Huang, L.; Chen, J. and Wang, Y. (1996). Antagonism of lactic acid bacteria towards Staphylococcus aureus and Escherichia coli on agar plates and in milk. Vet. Res., 27 (1): 3-12. (Abst.).

29- Pfeiffer, P. and Radler, F. (1982). Purification and Characterization of extracellular and intracellular killer toxin of Saccharomyces cerevisiae strain 28. J. Gen. Microbiol., 128: 26992706

30- Barefoot, S. F. and Kaenhammer, T. R. (1983). Detection and activity of Lactocin B. A bacteriocin produced by 
Lactobacillus acidophilus. Appl. uropthogenic Enterococcus faecalis by Environ. Microbiol., 45 (6): 1808-1815. biosurfactants from Lactobacillus 31- Reid, G.; Tieszer, C. and Lam, isolates. Appl. Environ. Microbiol. 62: D. (1990). Influence of Lactobacilli on 1958-1963. (Cited by Fergus M. C. the adhesion of Staphylococcus aureus and Candida albicans to fibers and epithelial cells. J. Ind. Microbiol: 15: 248-253. (Cited by Fergus M. C. (1999). (1999)

33-Fergus M. C. (1999). Probiotic Spectra of Lactic Acid Bacteria (LAB). Food Sci. and Nut. 39 (1): 17-43.

34-Lilley, D. M. and Stillwell, R. H. 32-Velraeds, M. M., Van der Mei, H. C., (1965). Probiotics : growth promoting Reid, G. and Busscher, H. J. (1996). factors produced by microorganism, Inhibition of initial adhesion of Science,; 147: 747-74 